\title{
Persistent Right Aortic Arch in a Dog
}

\author{
Ana Maria Quessada, Zilmara Cardoso Fonteles, Nádia Expedita de Almeida e Cruz, Marcelo Campos \\ Rodrigues, Marcus Valerius de Matos Freitas, Francisca Barros Bezerra \& João Macedo de Sousa
}

\begin{abstract}
Background: Vascular ring anomalies were congenital malformation of the great vessels, caused by defects in embryogenesis of the aortic arches. In dogs the most common type is persistent right aortic arch (PRAA). The PRAA occurs when the fourth right aortic arch persists instead of left to form the aorta. This malformation causes extraluminal compression of the esophagus up to the base of the heart. The constriction leads to esophageal dilatation secondary, located cranial to the base heart. The food, which can not progress beyond the narrowing, is regurgitated intermittently. Thus, the main clinical sign of disease is regurgitation when the patient starts eating solid foods. Respiratory clinical signs (mainly pneumonia by aspiration) may occur and can complicate the disease. The diagnosis is suspected by history (puppies at weaning) and physical examination. The diagnosis is confirmed by the esophagogram, where the image is characteristic (esophagic dilatation cranial base of the heart). The treatment of the affection is surgical, with transection and ligature of the vascular ring, viewed during thoracotomy by fourth intercostal space. The postoperative management which consists mainly of liquid diet and/or pasty is important for total recovery of the animal. In some cases, the animal must receive a special diet for life to prevent regurgitation. However at long term, most operated animal presents important sequels. These sequelae include respiratory disorders and low development of animal. The objective of the present paper is to relate a case of bitch with persistent right aortic arch, successful treated surgically, without serious clinical consequences.

Case: A mongrel bitch with 2 months of age was attended at the Veterinary Hospital of the Federal University of the Piauí, Brazil, with vomiting. At the clinical examination was observed increase in volume in the cervical region. Radiographic examination revealed dilatation cranial to the heart base, characterizing megaesohagus. The diagnosis was PRAA. The dog was submitted at thoracotomy by fourth right intercostal space. The ligamentum arteriosum was localized and ligated at the distal and craniallly. During transoperative was made blood transfusion for correction of the anemia detected in preoperative period. The chest wall was closed routinely. Two days after surgery the dog was discharged. The postoperative diet consisted of liquids for a week, followed by semi-solid food always in bipedal position. After discharge, the owner returned for monthly visits for a year, with completion of physical examination and radiographs.

Discussion: PRAA is most common in purebred dog, but in this case the animal is a mixed breed dog. The diagnosis was suspected due to history, and confirmed by esophagogram, where there was megaesophagus cranial to the heart base, according by literature. The surgical treatment, rapidly decided, and the absence of pneumonia, which is the main complication postsurgical, contributed to the observed good results. The blood transfusion to correct anemia also was important for the recovery of the animal. There is an esophageal dilatation after one year, however no clinical manifestation occurs. The dog has a normal life. Excellent results as in the case reported here have a slower rate than $10 \%$.
\end{abstract}

Keywords: congenital malformation, esophagus, megaesophagus, surgery. 


\section{INTRODUCTION}

Persistent right aortic arch (PRAA) accounts for $95 \%$ of cases of vascular ring anomalies in the dog [2] and occurs when the fourth right aortic arch persists instead of the left would form the aorta $[2,3]$. This malformation causes extraluminal compression of the esophagus, leading to secondary megaesophagus [2,3]. The main clinical sign is regurgitation when the patient starts eating solid foods because they cannot progress beyond the narrow [2$4,6]$. There may be pneumonia by aspiration, which can complicate the disease $[2-4,6]$. The diagnosis is suspected by history and physical examination, and confirmed by the esophagogram [3]. The treatment is surgical, with transection and ligature of the vascular ring, viewed during surgical procedure [24]. However at long term, most operated animal present important sequelae, like regurgitation $[4,5]$ and pneumonia [5,7].

This paper aims to report the case of a dog with PRAA diagnosed and treated surgically. The case is interesting because the animal was accompanied during one year with no clinic alterations or sequelae.

\section{CASE REPORT}

A mongrel bitch with 2 months of age was attended at the Veterinary Hospital of the Federal University of the Piauí, Brazil, with complaint of the vomiting. At the clinical examination was observed small increase in volume in the cervical region and discrete pulmonary stertor. Contrast radiographic

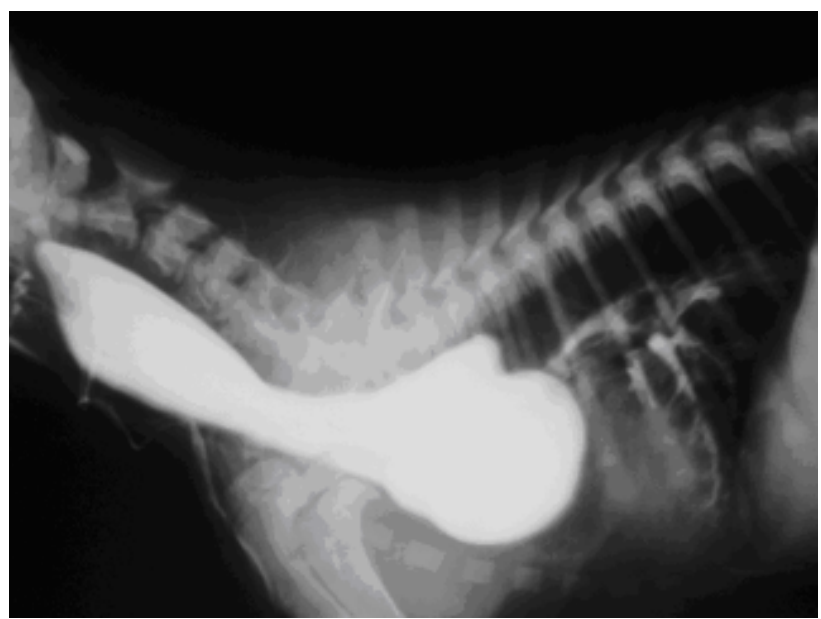

Figure 1. Radiography of the female mongrel dog with persistent right aortic arch. Observe cranial dilation esophageal at the base of the heart. examination revealed dilatation cranial to the base of the heart, confirming the suspicion of PRAA (Figure 1). The dog was referred for surgery.

Before surgery complete blood count was performed, observing anemia. The animal was subjected to fasting for $12 \mathrm{~h}$ solid and water for six. The anesthetic protocol consisted of sedation with acepromazine $^{1}(0.1 \mathrm{mg} / \mathrm{kg})$ intramuscularly, ketamine ${ }^{2}$ $(5 \mathrm{mg} / \mathrm{kg})$ associated with diazepan ${ }^{3}(0.2 \mathrm{mg} / \mathrm{kg})$ intravenously in the same syringe for induction. Maintenance was made with isoflurane ${ }^{4}$. Fluidotherapy was instituted with ringer lactate ${ }^{5}$ at a dose of $5 \mathrm{~mL} / \mathrm{kg} / \mathrm{hour}$ and whole blood at a dose of $15 \mathrm{~mL} / \mathrm{kg}$.

The thoracic cavity was opened in the fourth right intercostal space. The ligamentum arteriosum was ligated at the distal and cranial (Figure 2). The chest wall was closed routinely.

After surgery, the dog was hospitalized, being treated with metronidazole ${ }^{6}$ at $30 \mathrm{mg} / \mathrm{kg} \mathrm{sid}$, amoxicillin $^{7} 22 \mathrm{mg} / \mathrm{kg}$ bid, dexamethasone ${ }^{8}$ at 0.5 $\mathrm{mg} / \mathrm{kg}$ sid and tramadol ${ }^{9} 2 \mathrm{mg} / \mathrm{kg}$ tid. He also received intravenous Ringer lactate ${ }^{5}$ associated with glucose $50 \%{ }^{10}$. Two days after surgery was discharged. Suture skin was removed ten days after surgery. Antibiotic therapy was continued for another ten days after discharge. The postoperative diet consisted of liquids for a week, followed by semi-solid food always in bipedal position. This management has been recommended for a lifetime. After discharge, the owner returned for monthly visits for a year, with completion of physical examination and radiographs.

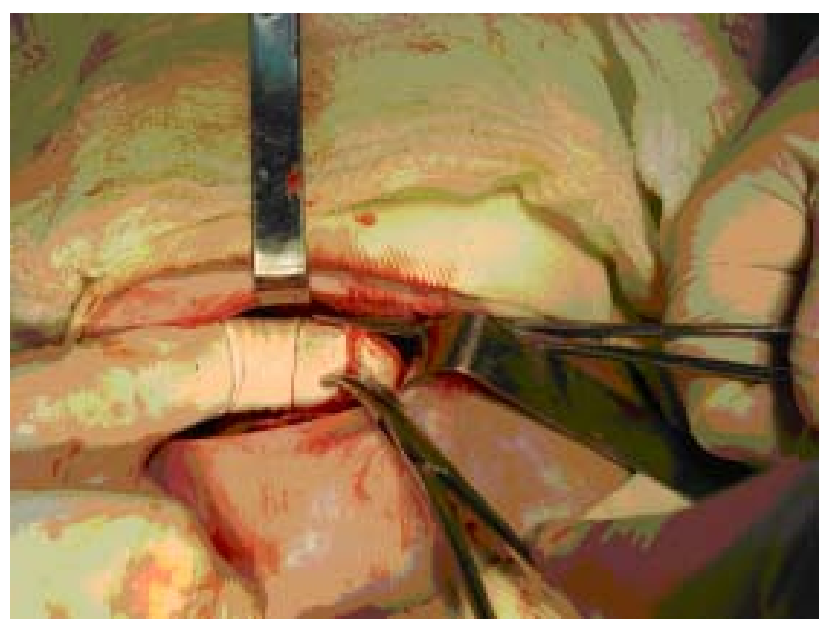

Figure 2. Thoracotomy in female mongrel dog with persistent right aortic arch. Observe ligament arteriosum clamped. 


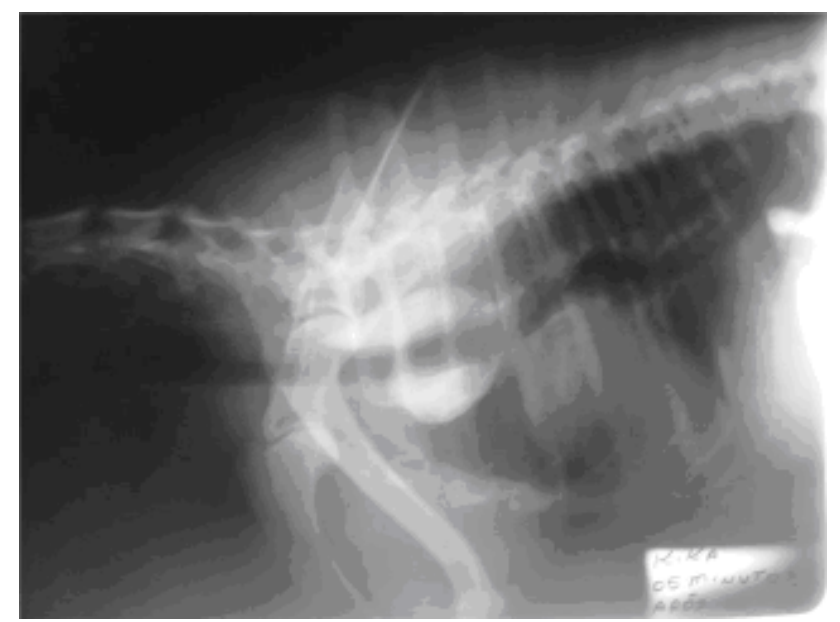

Figure 3. Radiography of the female mongrel dog with persistent right aortic arch one year after surgery to correct the condition. Observe cranial dilation esophageal at the base of the heart.

\section{DISCUSSION}

Purebred dogs are the most affected by the PRAA [2,3,6], but, in the case, reported here, the animal is a mixed breed dog. According to the literature, the diagnosis was made after two months of age [2] with the aid of the esophagogram [3], where there was megaesophagus cranial to the heart base [4]. There were no postoperative complications which are common in this surgery [1-3,5], including deaths [3] by poor clinical condition our euthanasia [1,5]. It is considered that the absence of pneumonia, which is the main complication [3,5], contributed to the outcome, as well as blood transfusion to correct anemia, probably related to malnutrition $[2,4]$.

The semi-solid diet in bipedal position was prescribed [3]. However, the owner feeds the animals with dry food in normal position with good results probably because the food is given in small portions.

Esophageal dilatation, still present after one year (Figure 3), is common in late postoperative of illness [4]. However, no clinical manifestation occurs and there is reduction of the diameter in comparison with the previous dilatation (Figure 1).

The dog has a normal life with proper body development and excellent quality of life. Excellent results as in the case reported here have a slower rate than $10 \%$ [7].

\section{SOURCES AND MANUFACTURERS}

${ }^{1}$ Acepran, Univet, São Paulo, SP, Brazil.

${ }^{2}$ Vetanarcol, Konig, São Paulo, SP, Brazil.

${ }^{3}$ Diazepam injetável, União Química, Embu-Guaçu, SP, Brazil.

${ }^{4}$ Forane, Abbott, São Paulo, SP, Brazil.

${ }^{5}$ Solução de Ringer com lactato, Endomed, Aquiraz, CE, Brazil.

${ }^{6}$ Flagyl injetável, Sanofi Aventis, Suzano, SP, Brazil.

${ }^{7}$ Amoxicilina, Infabra, Rio de Janeiro, RJ, Brazil.

${ }^{8}$ Dexametasona injetável, São Paulo, SP, Brazil.

${ }^{9}$ Tramal, Pfizer, Guarulhos, SP, Brazil.

${ }^{10}$ Solução de glicose 50\%, Endomed, Aquiraz, CE, Brazil.

\section{REFERENCES}

1 Colomé L.M., Ferreira R.R., Ferreira M.P., Contesini E.A., Beck C.A.C., Gaiga L.H., Oliveira E.C. \& Freire C.D. 2004. Correção cirúrgica da persistência do arco aórtico direito (paad) em cão. Arquivos de Ciência Veterinária e Zoologia da UNIPAR. 7(2)Suplemento: 40. Disponível em: <http:/tapajo.unipar.br/site/ensino/pesquisa/publicacoes/revistas/revis/ view03.php?ar_id=1634>

2 Hedlund C.S. \& Fossum T.W. 2008. Anomalia de anéis vasculares In: Fossum T.W. (Ed). Cirurgia de pequenos animais. 3.ed. São Paulo: Elsevier, pp.405-408.

3 Kyles A.E. 2007. Esôfago. In: Slatter D. (Ed). Manual de cirurgia de pequenos animais. 3.ed. São Paulo: Manole, pp.573592. 
4 Muldoon M.M., Birchard S.J. \& Ellison G.W. 1997. Long-term results of surgical correction of persistent right aortic arch in dogs: 25 cases (1980-1995). Journal of the American Veterinary Medical Association. 210(12): 1761-1763.

5 Oliveira E.C., Gaiga L.H., Colomé L.M., Stedile R. Melo F.P.S., Martins J.M. \& Freire C.D. 2004. Persistência do arco aórtico direito em um cão-relato de caso. Revista da FZVA. (11)1: 174-180.

6 Rodrigues B.A., Lamberts M., Muccillo M.S., Martins J.M., Ferreira M.P., Scherer S., Bruns C.F.L. \& Lampert M. 2007. Persistência de arco aórtico direito em fêmea da raça american staffordshire terrier tratada cirurgicamente com sucesso: relato de caso. Clínica veterinária. (12)67: 32-40.

7 Shires P.K. \& Liu W. 1981. Persistent right aortic arch in dogs: a long term follow-up after surgical correction. Journal of the American Animal Hospital Association. 17(5): 773-776. 